\title{
Peculiarities of plantation forestry on dried peat-steppes of the Forest-Steppe of Ukraine and its impact on soil
}

\author{
Virovka V., Helevera S., Pustovoitov Ya. \\ Panfyly Research Station of the NSC «Institute of Agriculture of the NAAS» \\ 2, Tsentralna Str., village Panfily, Yahotyn region, Kyiv oblast, 07750, Ukraine \\ e-mail: volodimiv@ukr.net
}

Goal. To determine the most adapted wood breeds for plantation afforestation of different function in the conditions of drained peatlands of the Forest-Steppe. To study the peculiarities of growth and development of newly created forest crops in specific conditions of organogenic soils. To determine the influence of afforestation on the change of water-physical properties of drained organogenic soils. Methods. General scientific (hypotheses, inductions and deductions, analogies, generalizations) and special (field, laboratory, mathematical, statistical, computational) - for research and their generalization. Results. The best indicators of productivity in these conditions were shown by tree and bush willows, black poplar, sticky alder, and hybrids of EuroAmerican poplars. The optimal length of unrooted cuttings for the creation of energy plantations was $25 \mathrm{~cm}$. For afforestation of black alder on drained organogenic soils, it is advisable to create forest crops with seedlings 1.0 $-1.2 \mathrm{~m}$ high according to the scheme $3.0 \times 1.0 \mathrm{~m}$, which ensures survival at the level of $98 \%$. Over the last 52 years, the density of peat in the upper layer $(0-30 \mathrm{~cm})$ in the forest stand has not changed (the difference is $3 \%$ ), while in the lower layers it has increased by $18-20 \%$, but the soil density remains low (average 0.250 $\mathrm{g} / \mathrm{cm} 3$ ) and high total moisture content (345\%). The decrease in soil mineralization in forest stands compared to hayfields indicates a slowdown in the decomposition of peat organic matter under the forest, which is important for the preservation of peatlands. After the cycle of plantation afforestation, re-agricultural use of lands with improved water-physical properties of the soil is possible. Conclusions. The creation of forest plantations on drained organogenic soils is quite possible and expedient. With the use of different species composition and changes in planting density, you can create plantations of tree crops for different purposes. The highest indicators of productivity in these conditions had tree and bush willows, black poplar, alder sticky and hybrids of Euro-American poplars.

Key words: tree plantations, survival, growth, potash fertilizer, biological activity, water-physical properties. DOI: https://doi.org/10.31073/agrovisnyk202102-08

One of the main tasks of drainage reclamation was and remains the expansion of areas for agricultural production. Today, the most appropriate is the use of these lands as a fodder base for livestock with a priority for growing perennial grasses. However, the weak economic condition of rural communities that have drained peatlands does not allow for productive use of these lands with a significant reduction in livestock, and to carry out timely repairs and modernization of the drainage network. This leads to overgrowing of weeds, unproductive loss of organic matter of peat, increasing the risk of fires.

On the other hand, there are powerful farms that use drained peatlands and appropriate technical and financial resources and can sow high-yielding and profitable row crops using chemicals. This, in turn, accelerates the mineralization of peat, often leads to wind erosion, increases the level of pollution of groundwater and, consequently, other reservoirs. Therefore, the introduction of technologies that minimize the impact on the environment and bring anthropogenically developed area to natural ecosystems is relevant for management of drained organogenic soils, which have already significantly changed their condition due to land reclamation.

In this regard, one of the possible ways to improve the situation is to grow tree plantations for various purposes, primarily for the rapid production of wood. It should be noted that research on afforestation in drained peatlands was conducted mainly on upland swamps (Karelia, the Baltic States, Belarus), and they concerned the creation of forests on newly drained lands. Studies of the peculiarities of afforestation in the old arable carbonate peatlands of the Forest-Steppe of Ukraine were carried out in a limited volume, moreover, without sufficient scientific substantiation. However, the specific conditions of drained peatlands, namely: relatively high groundwater levels, specific water-physical and agrochemical soil conditions, high competition with natural vegetation, slightly different temperatures and reduced growing season, require special selection of crops [1 7].

A significant advantage of plantation afforestation on organogenic soils is earlier maturity, compared with similar plantations on rich mineral, naturally drained soils of land [8]. This is best in line with the idea of creating tree plantations, as in accordance with DSTU 2980-95 "Forest crops. Terms and definitions "[9], plantation forest crops are forest crops with accelerated plant growth, created to reduce the time of growing special forest products of high quality. The main purpose of forest plantations is to obtain the maximum number of products per unit area.

As potentially fertile, but excessively moist, peat bogs belong to the subtree trophotopes - C. Prior to drainage, woody vegetation was represented mainly by small forests of alder and birch, in the second tier dominated by shrub species of willows, buckthorn, rarely hazel. The degree of coverage of the territory reached 
$40 \%$ [10]. After drainage, the hygrotopes changed to wet - 4 and wet - 3 , and soil fertility, due to mineralization of organic matter and long-term agricultural use, increased to dibrovnyh conditions - D.

Such conditions are optimal for growing plantations of fast-growing species, namely poplar, willow, black alder.

The purpose of research. Install the most suitable wood species for plantation afforestation for various purposes in the conditions of drained peatlands of the Forest-Steppe. Investigate the features of growth and development of newly created forest crops in specific conditions of organogenic soils. To study the influence of tree plantations on the main water-physical properties of the drained peat bog. Assess the possibilities of further agricultural use of lands after the cycle of plantation afforestation.

Materials and methods of research. Research on forest management of drained peatlands was conducted by the Panphilic Research Station of the NSC "Institute of Agriculture NAAS" in 2005 - 2011. In the following years, research was conducted on the species composition of trees and shrubs, the optimal agricultural techniques for creating plantations were determined, and the effect of potash fertilizers on forest crops was studied.

The soil of the experimental plots is characterized by the following indicators: carbonate soil (37 - 49\%), water $\mathrm{pH} 7.3-7.8$, depth of peat $3-4 \mathrm{~m}$, decomposition of peat in the arable layer $65-70 \%$, bulk density $0.375-$ $0.435 \mathrm{~g} / \mathrm{cm} 3$, ash content $39-57 \%$, gross nitrogen content $1.57-1.89 \%$, phosphorus $0.45-0.76 \%$, potassium $0.09-0.12 \%$.

The intensity of $\mathrm{CO}_{2}$ release was determined by the method of $\mathrm{B}$, I, Shtatnov, and the cellulose-destroying activity of the microflora by the method of applications. Water-physical characteristics of the soil were determined by generally accepted methods in agronomy. Statistical processing was carried out according to the "Methods of field experience (with the basics of statistical processing of research results)" edited by BA Armored.

Research results. The main factor that determines the ability of wood species to grow and develop on drained lands is their biological adaptation to conditions of excessive humidity, when the groundwater level even in the summer months is $60-120 \mathrm{~cm}$ (Table 1), and in the cold season fluctuates within $10-45 \mathrm{~cm}$ from the soil surface. It is also important to take into account the specifics of carbonate peatlands, namely the alkaline reaction of the soil solution ( $\mathrm{pH}>7.0)$, and the lack of one of the main nutrients - potassium.

1. Groundwater level, $\mathrm{cm}$ from the soil surface, $\mathrm{cm}$

\begin{tabular}{|c|c|c|c|c|c|c|c|c|}
\hline \multirow{2}{*}{ Year } & \multicolumn{6}{|c|}{ Month } & \multirow{2}{*}{ average } \\
\cline { 2 - 8 } & April & May & June & July & August & September & October & \\
\hline 2005 & 40 & 44 & 43 & 71 & 60 & 67 & 66 & 56 \\
\hline 2006 & 24 & 28 & 32 & 68 & 78 & 74 & 57 & 52 \\
\hline 2007 & 42 & 67 & 82 & 104 & 122 & 120 & 91 & 90 \\
\hline 2008 & 37 & 59 & 81 & 71 & 96 & 86 & 62 & 70 \\
\hline 2009 & 47 & 68 & 83 & 106 & 125 & 140 & 101 & 96 \\
\hline 2010 & 44 & 70 & 97 & 132 & 155 & 116 & 88 & 100 \\
\hline 2011 & 46 & 68 & 100 & 56 & 64 & 91 & 61 & 69 \\
\hline average & 40 & 58 & 74 & 87 & 100 & 99 & 75 & \\
\hline
\end{tabular}

It should be noted that 2007, 2009 and 2010 were arid years, which provided the lowest groundwater levels, and 2008 was characterized by more rainfall, which allowed to obtain optimal groundwater levels for major crops (average $70 \mathrm{~cm}$ per growing season).

As the amount of precipitation increases, the groundwater level increases, and its greatest decrease occurs during the period with the minimum amount of precipitation. Thus, in August 2007, 55.8\% of the average norm fell, which lowered the water level to $122 \mathrm{~cm}$, and in August - September $2009-19.6 \%$ and $46.7 \%$, respectively, which led to a level of $125-140$ In July-August 2010, 45\% of the average long-term precipitation was recorded. In the driest periods, the water level dropped below $100 \mathrm{~cm}$ from the soil surface and in some water wells reached $165 \mathrm{~cm}$.

Slightly alkaline and close to neutral reaction of the soil solution of carbonate peatlands of the Forest-Steppe of Ukraine does not allow afforestation with coniferous species (Scots pine, spruce, white fir, etc.), so the main attention should be paid to deciduous trees growing in our area. opportunities to select planting material from drained areas, local aborigines.

It was established (Table 2) that all studied breeds were characterized by good survival $-86.3-96.4 \%$ and intensive growth in height, up to $2.4 \mathrm{~m}$ per year. A feature of poplar plantations is their versatility. So for their 
wide-row planting, in our case $6.0 \times 6.0 \mathrm{~m}$, we will later receive large assortments of commercial wood (up to $400 \mathrm{~m} 3$ / ha at the age of 30 years), and for dense planting (15 thousand pieces per 1 ha) - short-rotation energy plantations for fuel chips. In addition, increasing the width between rows and rows in the created plantations to $8 \times 8$ or $10 \times 10 \mathrm{~m}$ allows to grow under the tent of the main plantings allows others [17]. crops, including perennial grasses for hay or pasture use.

Willow plantations are more resistant than others to long-term stagnant moisture, and the technology of creation and use are similar to poplar.

Shrub willows - three-stemmed and twig-shaped - should be singled out. Their high productivity allows to receive in a two-year increment up to 45 tons of dry matter per hectare, which is equivalent to energy productivity in 314 GJ / ha.

The technology of creating alder crops on drained peatlands is little different from crops on mineral soils [11], the lack of potassium inhibits the growth of seedlings in the first years after planting. In the spring of 2007, alder seedlings were planted on the lands of the Panfil Research Station according to the $3.0 \times 1.0$ m scheme and in three ways of soil preparation: furrow plowing with a double-plow; milling; milling with the subsequent formation of micro-elevations; with control - without cultivation. Due to the lack of potassium in the peat soil, we introduced a plot with the introduction of K180 according to the scheme (Table 3).

Observations of alder growth in the control area (without cultivation) show that in the first two years (2007, 2008) the planted seedlings grew poorly both in height - $19.6 \mathrm{~cm}$ per year and in diameter - 3.2 and $3.6 \mathrm{~mm}$.

\section{Comparative characteristics of survival and growth of plantations of fast-growing species, data from 2008}

\begin{tabular}{|l|c|c|c|c|}
\hline \multicolumn{1}{|c|}{ Species name } & $\begin{array}{c}\text { Age, } \\
\text { years }\end{array}$ & $\begin{array}{c}\text { Planting } \\
\text { scheme, } \mathrm{m}\end{array}$ & Survival,\% & $\begin{array}{c}\text { Average plant } \\
\text { height, } \mathrm{m}\end{array}$ \\
\hline Black poplar - Populus nigra L. & 3 & $6.0 \times 6.0$ & 86.3 & 5.5 \\
\hline $\begin{array}{l}\text { Poplar 'Powerful' - (Populus } \times \\
\text { euramericana) 'robusta' }\end{array}$ & 3 & $6.0 \times 6.0$ & 91.2 & 7.1 \\
\hline Black alder - Alnus glutinosa L. & 6 & $3.0 \times 0.5$ & 93.1 & 9.5 \\
\hline White willow - Salix alba L. & 6 & $3.0 \times 1.0$ & 95.0 & 11.9 \\
\hline Willow twig - Salix viminalis L. & 2 & $0.7 \times 0.9$ & 96.4 & 5.1 \\
\hline Willow tritichinkova - Salix triandra L. & 2 & $0.7 \times 0.9$ & 95.1 & 5.5 \\
\hline
\end{tabular}

In the third year, in the version without potash fertilizer, the increase in height increased by $20 \%$, and in the fourth year it increased 2.1 times compared to the third year. In diameter, these plantations increased by $30 \%$ and 2.1 times. Significantly improved the condition of the created crops with the introduction of potash fertilizers. Thus, in 2009 the difference in growth in height compared to the unfertilized area was $39.2 \mathrm{~cm}$, and the fourth $103 \mathrm{~cm}$, or more than three times, which is the maximum of all surveyed areas, and indicates a high efficiency of application potassium fertilizer on peat soils not only for growing crops, but also for forestry use.

\section{Growth of alder sticky depending on the method of soil preparation and fertilizer}

\begin{tabular}{|c|c|c|c|c|c|c|c|c|c|}
\hline \multirow{3}{*}{$\begin{array}{c}\text { The method } \\
\text { of soil } \\
\text { preparation }\end{array}$} & \multirow{3}{*}{ Fertilizer } & \multicolumn{8}{|c|}{ Growth over the years } \\
\hline & & \multicolumn{4}{|c|}{ In height, see } & \multicolumn{4}{|c|}{ By diameter, $\mathrm{mm}$} \\
\hline & & 2007 & 2008 & 2009 & 2010 & 2007 & 2008 & 2009 & 2010 \\
\hline \multirow{2}{*}{$\begin{array}{l}\text { Without } \\
\text { cultivation }\end{array}$} & $\begin{array}{l}\text { without } \\
\text { fertilizers }\end{array}$ & 19.6 & 19.6 & 23.6 & 50.6 & 3.2 & 3.6 & 4.7 & 9.8 \\
\hline & $\mathrm{K}_{180}$ & - & - & 62.8 & 153.7 & - & - & 5.5 & 13.2 \\
\hline \multirow{2}{*}{$\begin{array}{l}\text { At the } \\
\text { bottom of } \\
\text { the furrows }\end{array}$} & $\begin{array}{l}\text { without } \\
\text { fertilizers }\end{array}$ & 23.7 & 30.4 & 56.5 & 98.6 & 4.5 & 4.8 & 6.4 & 10.9 \\
\hline & $\mathrm{K}_{180}$ & - & - & 94.1 & 167.5 & - & - & 9.8 & 16.7 \\
\hline \multirow{2}{*}{ On the ridge } & $\begin{array}{l}\text { without } \\
\text { fertilizers }\end{array}$ & 24.9 & 24.0 & 39.8 & 78.0 & 4.8 & 5.2 & 5.0 & 9.8 \\
\hline & $\mathrm{K}_{180}$ & - & - & 49.6 & 146.9 & - & - & 5.4 & 15.7 \\
\hline
\end{tabular}




\begin{tabular}{|c|c|c|c|c|c|c|c|c|c|}
\hline \multirow{3}{*}{ By milling } & $\begin{array}{c}\text { without } \\
\text { fertilizers }\end{array}$ & 19.8 & 20.5 & 21.2 & 61.1 & 3.9 & 4.5 & 4.2 & 11.7 \\
\cline { 2 - 10 } & $\mathrm{K}_{180}$ & - & - & 50.4 & 120.3 & - & - & 5.1 & 12.0 \\
\hline \multicolumn{2}{|c|}{ NIR $_{05}$} & 3.4 & 5.8 & 30.5 & 43.3 & 0.4 & 0.8 & 2.0 & 3.9 \\
\hline
\end{tabular}

An important factor influencing successful afforestation is the size of the planting material. Obviously, high competition from grass vegetation does not allow planting one-two-year seedlings. On the other hand, large seedlings increase the cost of established plantations. To study the optimal size of planting material, an analysis of the growth and survival of birch and alder seedlings depending on the initial height (Table 4). According to the given data it is expedient to create alder cultures by alder saplings $80-140 \mathrm{~cm}$ high. Such sizes provide survival at the level of $94-98 \%$ and increase in height at the level of $25 \mathrm{~cm}$ in the first two years. Some alder and birch saplings with a height of more than $150 \mathrm{~cm}$ took up relatively well -86.7 and $69.0 \%$, respectively, and the state of the root system played a decisive role here.

\section{Growth of tree seedlings in the first two years depending on the height}

\begin{tabular}{|c|c|c|c|c|}
\hline \multirow{2}{*}{$\begin{array}{c}\text { Initial height of } \\
\text { seedlings, see }\end{array}$} & \multicolumn{2}{|c|}{ Seedling growth, see } & \multicolumn{2}{c|}{ Survival,\% } \\
\cline { 2 - 5 } & Alder & Birch & Alder & Birch \\
\hline up to 60 & $17.3 \pm 0.88$ & $14.3 \pm 0.86$ & 81.3 & 88.6 \\
\hline $61-80$ & $19.5 \pm 0.78$ & $12.1 \pm 0.61$ & 90.2 & 82.3 \\
\hline $81-100$ & $24.5 \pm 0.49$ & $11.1 \pm 0.78$ & 95.1 & 80.1 \\
\hline $101-120$ & $25.7 \pm 0.88$ & $9.3 \pm 0.63$ & 98.7 & 72.8 \\
\hline $121-140$ & $25.3 \pm 0.76$ & $8.1 \pm 0.64$ & 94.3 & 70.1 \\
\hline $141-160$ & $20.8 \pm 1.25$ & $8.0 \pm 0.48$ & 84.5 & 66.4 \\
\hline$>161$ & $17.6 \pm 0.87$ & $14.3 \pm 0.77$ & 86.7 & 69.0 \\
\hline
\end{tabular}

Studies of minirotation willow plantations for the production of solid biofuels indicate the inevitability of their creation by stem unrooted cuttings of one year of age [13]. This is due to the high planting density - 15 thousand pieces / ha and more, and the impossibility of using planting machines to work with already rooted annual cuttings. The recommended length of cuttings is $25 \mathrm{~cm}$, diameter $-1-3 \mathrm{~cm}$.

Due to the presence of forest litter, which diversifies the soil fauna and microflora, as well as increases their number, forest plantations mostly have a positive effect on the water and physical properties of the soil. Thus, according to EG Polyakov, VA Sukachev, AA Shchurevich [12-14], soil density under forest stands begins to decrease after the closure period (5 years) and reaches stable values at $20-25$ years of age. , exceeding not forested areas in 1,5-2,5 times. Additional effect on the density of the upper $0-30 \mathrm{~cm}$ of the layer is caused by tillage equipment, which is absent in the forest and is widely used for growing row crops.

Studies of water-physical properties of drained peat soil under different coenoses (Table 5) indicate a significant difference between these indicators, especially soil density and total moisture content. Thus, under maize crops, the upper $30 \mathrm{~cm}$ layer of soil had a soil density of $0.597 \mathrm{~g} / \mathrm{cm} 3$, which is $1.6-1.8$ times higher than under perennial grasses, and 2.4 times higher than under forest plantations. Respectively, the total moisture content of peatlands under row crops relative to hayfields and forests was 1.8-2.7 times lower. The soil density under forest stands differed significantly from these indicators under grass stands and exceeded the soil density in the lower $(30-60 \mathrm{~cm})$ layer compared to $(0-30 \mathrm{~cm})$ by $2.2 \%$. This is due to the regular inflow to the upper layer of forest rainfall.

\section{Influence of biocenoses on water-physical properties of peat soils (average for 2008 - 2010)}

\begin{tabular}{|c|c|c|c|c|}
\hline Biocenosis & $\begin{array}{c}\text { Soil layer, } \\
\text { see }\end{array}$ & Toughness, $\%$ & $\begin{array}{c}\text { Soil density, g / } \\
\text { cm3 }\end{array}$ & $\begin{array}{c}\text { Total moisture } \\
\text { content, } \%\end{array}$ \\
\hline \multirow{2}{*}{ Silage corn } & $0-30$ & 75.8 & 0.597 & 127 \\
\cline { 2 - 5 } & $30-60$ & 83.2 & 0.37 & 222 \\
\hline \multirow{2}{*}{ Area of re-waterlogging } & $0-30$ & 85.3 & 0.235 & 363 \\
\cline { 2 - 5 } & $30-60$ & 89.0 & 0.206 & 432 \\
\hline \multirow{2}{*}{ Birch forest } & $0-30$ & 86.2 & 0.250 & 345 \\
\cline { 2 - 5 } & $30-60$ & 84.3 & 0.285 & 300 \\
\hline \multirow{2}{*}{$\begin{array}{c}\text { Perennial herbs of the fourth year } \\
\text { of use } \mathrm{N}_{60} \mathrm{P}_{45} \mathrm{~K}_{120}\end{array}$} & $0-30$ & 83.2 & 0.334 & 249 \\
\cline { 2 - 5 } & $30-60$ & 82.8 & 0.345 & 240 \\
\hline
\end{tabular}




\begin{tabular}{|c|c|c|c|c|}
\hline \multirow{2}{*}{$\begin{array}{c}\text { Natural grassland without } \\
\text { fertilizers }\end{array}$} & $0-30$ & 83.4 & 0.369 & 226 \\
\cline { 2 - 5 } & $30-60$ & 83.1 & 0.338 & 246 \\
\hline \multirow{2}{*}{ NIRo5 } & $0-30$ & & 0.052 & \\
\cline { 2 - 5 } & $30-60$ & & 0.044 & \\
\hline
\end{tabular}

To study the change in the density of peat soil under the forest, a comparison was made with data from 1957 (Table 6).

\section{Change of the basic water-physical properties of peat soil on a site under forest cultures}

\begin{tabular}{|c|c|c|c|c|c|c|}
\hline \multirow{3}{*}{$\begin{array}{c}\text { Ball of } \\
\text { peat, see }\end{array}$} & \multicolumn{3}{|c|}{1957 (according to M.K. Sheiko) } & \multicolumn{3}{|c|}{2009} \\
\hline & \multicolumn{2}{|c|}{ density, $\mathrm{g} / \mathrm{cm}^{3}$} & \multirow[b]{2}{*}{$P V, \%$} & \multicolumn{2}{|c|}{ density, $\mathrm{g} / \mathrm{cm}^{3}$} & \multirow[b]{2}{*}{$P V, \%$} \\
\hline & $\begin{array}{l}\text { solid phase } \\
\text { of the soil }\end{array}$ & soil intact & & $\begin{array}{l}\text { solid phase } \\
\text { of the soil }\end{array}$ & soil intact & \\
\hline $0-30$ & 1.96 & 0.257 & 334 & $2.20 \pm 0.121$ & $0.250 \pm 0.014$ & 337 \\
\hline $30-50$ & 1.98 & 0.243 & 352 & $2.43 \pm 0.142$ & $0.291 \pm 0.015$ & 295 \\
\hline $50-75$ & 2.24 & 0.206 & 432 & $2.76 \pm 0.179$ & $0.243 \pm 0.014$ & 352 \\
\hline
\end{tabular}

Analysis of these data shows that over the past 52 years, the density of peat in the upper $30 \mathrm{~cm}$ layer has not changed (difference of 3\%), while in the lower layers there has been an increase in density by $18-20 \%$, which in our opinion is due to physical compaction of peat under the action of drainage reclamation. As a result, in the upper layer of peat, soil moisture content has not changed, and in the lower layers decreased by 16 $18 \%$.

Thus, forest plantations on drained peatlands, compared to soils sown with perennial grasses, have less effect on the change of their water-physical properties, especially in the upper $30 \mathrm{~cm}$ layer of soil. At the same time, the soil density is low $\left(0.250 \mathrm{~g} / \mathrm{cm}^{3}\right)$ and high total moisture content $(345 \%)$. The greatest impact on the water and physical properties of peat has the cultivation of row crops. Even short-term (4 years) continuous cultivation of corn increased the density of the arable layer to $0.597 \mathrm{~g} / \mathrm{cm}^{3}$, reducing the porosity to $75.8 \%$ and total moisture content to $127 \%$.

Four-year results of studies of the biological activity of drained peatlands under different biocenoses (Table 7) indicate different biological activity with different ways of using drained peatlands. The highest $\mathrm{CO} 2$ emissions occurred in early summer in birch and alder forests and averaged 2072 and $2041 \mathrm{mg} / \mathrm{kg}$ of soil per day, respectively. The maximum values were recorded in June $2010-2318-2433 \mathrm{mg} / \mathrm{kg}$ of soil per day. The least carbon dioxide was released in the non-drained swamp in the spring - an average of $378 \mathrm{mg} / \mathrm{kg}$ of soil per day, with a minimum value of $307 \mathrm{mg} / \mathrm{kg}$ in May 2008, which is due to the high saturation of the soil at this time with moisture. It was found that the decomposition of linen fabric in the forest during the whole time of observations was $2.9-16.0 \%$. At the same time, at the time of the largest decrease in groundwater levels (August September), the decomposition of fiber in the non-drained swamp (14.3\%) exceeded that of birch forest (8.5\%). The highest tissue decomposition was recorded on arable land in June $2007-45.9 \%$ at the lowest respiration rates $-320-1067 \mathrm{mg} / \mathrm{kg}$ of soil per day on average for the entire period of observations.

\section{Biological activity of soil in different biocenoses, average for 2007-2010}

\begin{tabular}{|c|c|c|c|c|c|c|c|c|}
\hline \multirow[b]{2}{*}{ Biocenosis } & \multicolumn{4}{|c|}{ Decomposition of linen fabric, $\%$} & \multicolumn{4}{|c|}{ Emission of $\mathrm{CO}_{2}, \mathrm{mg} / \mathrm{kg}$ of soil per day } \\
\hline & $\stackrel{\vec{\pi}}{\sum}$ & $\stackrel{0}{5}$ & 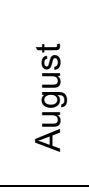 & 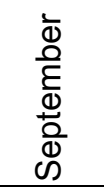 & $\stackrel{\vec{\pi}}{2}^{\vec{\pi}}$ & $\stackrel{0}{5}$ & $\begin{array}{l}\bar{n} \\
\frac{0}{0} \\
\frac{0}{2}\end{array}$ & 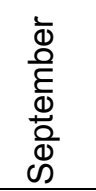 \\
\hline Birch forest & 4.6 & 5.7 & 8.5 & 2.9 & 1552 & 2072 & 1101 & 797 \\
\hline Alder forest & 5.1 & 6.5 & 16.0 & 3.9 & 1639 & 2041 & 1065 & 704 \\
\hline Hayfield without fertilizers & 2.8 & 9.6 & 21.7 & 6.9 & 940 & 1496 & 1427 & 513 \\
\hline The hayfield is fertilized & 15.7 & 23.5 & 31.4 & 7.9 & 1292 & 1835 & 1152 & 735 \\
\hline The swamp is not drained & 0.8 & 2.6 & 14.3 & 2.4 & 378 & 1170 & 1537 & 834 \\
\hline Arable & 26.6 & 37.8 & 32.8 & 16.6 & 793 & 1067 & 812 & 320 \\
\hline NIR 05 & 0.5 & 0.7 & 1.3 & 0.8 & 153 & 227 & 163 & 113 \\
\hline
\end{tabular}


High respiration in a non-drained swamp in August (up to $1918 \mathrm{mg} / \mathrm{kg}$ ) is also indicative, when the groundwater level decreases due to drought.

The process of determining the mineralization and biological activity in peat is complicated when the organic component of the soil is added organic matter from plant residues (wood residue, crop residues, etc.) In addition, the remnants of grass vegetation in the process of decomposition along with bacteria and fungi, and in the decomposition of deciduous and wood residues the decisive role is played by the fungal microflora.

Intermediate place is occupied by the results for fertilized and unfertilized hayfields. The highest $\mathrm{CO}_{2}$ emissions were observed on fertilized hayfields in June and averaged $1835 \mathrm{mg} / \mathrm{kg}$ of soil, which is due to the action of fertilizers and intensive growth of grasses, and in July this figure decreased by $37 \%$. The largest decomposition of linen fabric was recorded in July, $22.9-38.0 \%$, which is typical for unfertilized haymaking. At the same time, there is a smaller decrease in respiration in June - July by $6-21 \%$, and the decomposition of fiber is $21.7 \%$ in June, which is less than on fertilized hay by $9.7 \%$.

According to Academician VA Sukachev [14], wood residues are not available to bacteria due to the presence of tannins and the presence of lignin, which even fungi, with more active enzymes than bacteria, decompose for a long time.

Thus, by creating forest crops on drained peatlands, it is possible to influence the biological activity of the soil, which is closely related to the nutrient regime of the soil. Reduction of fiber decomposition in forest stands compared to haymaking indicates a slowdown in the decomposition of peat organic matter under the forest, which is important for the preservation of peatlands. At the same time, the increase in the amount of nutrients in the forest soil, compared to arable land and hayfields, is a natural property of tree phytocenoses that usually grow in poorer soil conditions. Therefore, artificial afforestation of drained organogenic soils is more expedient to carry out fast-growing species with the creation of plantations of the plantation type, which will contribute to better use of high potential fertility of these lands.

\section{Conclusions}

Creation of forest plantations on drained organogenic soils of the Forest-Steppe is quite possible and expedient. Using different species composition and changing the planting density, you can create plantations of tree crops for different purposes. The best indicators of productivity in these conditions were shown by tree and bush willows, black poplar and hybrids of Euro American poplars, as well as alder sticky. The optimal length of unrooted cuttings for the creation of energy plantations is $25 \mathrm{~cm}$. For afforestation of black alder on drained organogenic soils, it is advisable to create forest crops with seedlings 1.0-1.2 m high, according to the scheme $3.0 \times 1.0 \mathrm{~m}$. provides survival at the level of $98 \%$. Over the last 52 years in the forest stand, the density of peat in the upper $30 \mathrm{~cm}$ layer has hardly changed (difference of 3\%), at the same time, in the lower layers there was an increase in density by 18-20\%, low soil density along the entire soil profile (average $0.250 \mathrm{~g} / \mathrm{cm} 3$ ) and high total moisture content (345\%). Decreased soil mineralization in forest stands compared to hayfields indicates a slowdown in the decomposition of peat organic matter under the forest, which is important for the preservation of peatlands. At the same time, after the cycle of plantation afforestation, re-agricultural use of lands with improved water-physical properties of the soil is possible. which is important for the preservation of peatlands. At the same time, after the cycle of plantation afforestation, re-agricultural use of lands with improved waterphysical properties of the soil is possible. which is important for the preservation of peatlands. At the same time, after the cycle of plantation afforestation, re-agricultural use of lands with improved water-physical properties of the soil is possible.

\section{References}

1. Tkach, V.P. (1999). Zaplavni lisy Ukrainy [Floodplain forests of Ukraine]. Kharkiv: Pravo. [in Ukrainian].

2. Raspopina, S.P., \& Vedmid, M.M. (2018). Metodolohichni pidkhody do lisotypolohichnoi otsinky zemel, pryyniatykh pid zalisennia [Methodological approaches to forest typological assessment of lands accepted for afforestation]. Agrochemistry and soil science. Special. issue to the XI Congress of UTGA. T. 1. Pedology. Kharkiv: PP Stil Izdat, 225 - 227. [in Ukrainian].

3. Raspopina, S.P. (2019). Lesorastitelnaya diagnostika pochv. Lesnye pochvy i funktsionirovanie lesnykh ekosistem: mater. Vseros, nauchn. konf. S mezhdunar. uchastiem. Forest soil diagnostics [Forest soils and the functioning of forest ecosystems: mater. of the All-Russian Scientific Conference]. Moscow: TsEPL RAN. [In Russian].

4. Maurer, V.M., \& Brovko, F.M. (Kyiv, November 6-8, 2019). Vidtvorennia lisiv ta lisova melioratsiia $v$ Ukraini: vytoky, suchasnyi stan, vyklyky sohodennia ta perspektyvy $v$ umovakh antropotsenu [Forest reproduction and forest reclamation in Ukraine: origins, current state, current challenges and prospects in the Anthropocene]. Mater. international scientific-practical conference dedicated to the 100th anniversary of the Department of Forest Reproduction and Forest Reclamation. Kyiv: Lira-K. [in Ukrainian].

5. Krasnov, V.P., Shelest, Z.M., \& Davydova, I.V. (2014). Fitoekolohiia z osnovamy lisivnytstva [Phytoecology with the basics of forestry]. Textbook. Kherson: Oldi-Plius. [in Ukrainian].

6. Matyuk, I.S. (1983). Ustoychivost lesonasazhdeniy. [Sustainability of forest plantations]. Moscow: Lesnaya promyshlennost. [In Russian]. 
7. Orekhovskiy A.R. (1962). Ustoychivost ivy beloy i drugikh drevesnykh porod k dlitelnomu zatopleniyu [Resistance of white willow and other tree species to prolonged flooding]. Zashchitnaya zona Dnepra [Protective zone of the Dnieper]. Kiev: Izd-vo UASKhN, 154 - 170. [In Russian].

8. Sozdanie lesokultur na osushennykh bolotakh: rekomendatsii Leningradskogo instituta lesnogo khozyaystva (1964). [Creation of forest cultures on drained bogs: recommendations of the Leningrad Institute of Forestry]. Moscow: Nauka. [In Russian].

9. DSTU 2980 - 95. Lisovi kultury. Terminy ta vyznachennia [Forest crops. Terms and definitions]. [in Ukrainian].

10. Ryzhuk, S.M., \& Sliusar, I.T. (2006). Ahroekolohichni osnovy efektyvnoho vykorystannia osushuvanykh gruntiv Polissia i Lisostepu Ukrainy [Agroecological bases of effective use of drained soils of Polissya and Forest-steppe of Ukraine]. Kyiv: Ahrarna nauka. [in Ukrainian].

11. Fuchylo, Ya.D., \& Sbytna, M.V. (2017). Verby Ukrainy: biolohiia, ekolohiia, vykorystannia [Willows of Ukraine: biology, ecology, use]. Kyiv: Komprynt. [in Ukrainian].

12. Polyakov, Ye.G. (1973). Sozdanie produktivnykh nasazhdeniy na osushennykh zemlyakh [Creation of productive plantations on drained lands]. Moscow: Lesnaya

1. promyshlennost. [In Russian].

13. Shchurevich, A.A. (1977). Lesovyrashchivanie na osushennykh bolotakh [Forest growing in drained bogs]. Minsk: Uradzhay. [In Russian].

14. Sukachev, V.A. (1957). Osnovy lesnoy biotsenologii [Fundamentals of forest biocenology]. Leningrad: Gidrometizdat. [In Russian].

15. Roik, M.V., Sinchenko, V.M., Fuchylo, Ya.D. at al. (2016). Enerhetychna verba: tekhnolohiia vyroshchuvannia ta vykorystannia [Energy willow: technology of cultivation and use]. Vinnytsia: TOV «Niland LTD». [in Ukrainian].

16. Humentyk, M.la., Radeiko, B.M., Fuchylo, Ya.D. at al. (2018). Vyroshchuvannia bioenerhetychnykh kultur [Growing bioenergy crops]. Kyiv: TOV «TsP «Komprynt». [in Ukrainian].

17. Moten, N. (1982). Nach - und Neuansaat von Schafweiden. Deutsche Schafzucht, 74, $212-214$. 